\title{
The Numerical Simulation and Study on Gymnasium Indoor Thermal Environment of Airpak
}

\author{
Feng Qian and Li Yang* \\ College of Architecture and Urban Planning, Tongji University, Key Laboratory of Ecology and Energy Saving Study of Dense \\ Habitat (Tongji University), Ministry of Education, Shanghai, P. R. China \\ ${ }^{*}$ Corresponding author
}

\begin{abstract}
The paper chose the design of activity center of the gymnasium located in Dangtu County as an example, based on the structure characteristics of the stadium. The software Airpak 2.1 is used to simulate air flow organization (airflow velocity and temperature) and thermal comfort of the sports games hall (including the competition area and audience area) without the audience in a typical summer conditions. The results were analyzed and shall provide a theoretical basis and guiding value for the optimization design of the multi-functional stadium indoor environment.
\end{abstract}

Keywords-gymnasium; indoor thermal environment; air distribution; thermal comfort; numerical simulation

\section{INTRODUCTION}

With the development of society, economy, our living standard raised. So are our sports undertakings especially in recent years. Our sports undertakings have been greatly improved at home and abroad, the masses also actively participate in sports. The passion of national sports booms up at that time. That reflects people pursue of positive, healthy and high quality life. All kinds of sports facilities ceaselessly increase especially the investment of gymnasium construction, and so is the higher indoor environment of large space structure. The gymnasium is a large space building with big volume, more heat of the maintenance structure, intensive personnel and light, and heavy load of air condition [1]. It should fulfill the requirements of healthy, comfortable, energy's effective utilization and environment protection. For this purpose, design the reasonable airflow organization of the air distribution to meet the requirements of the competition and the audience. It is important to assure the quality of indoor air, save energy and take the road of sustainable development.

It is hard to accurately analyze and assess air organization of large space structure such as gymnasium by the conventional design method. The paper chose the design of activity center of the gymnasium located in Dangtu as an example. The software Airpak 2.1 is used to simulate air flow organization (airflow velocity and temperature) and thermal comfort of the sports games hall (including the competition area and audience area) without the audience in a typical summer conditions [2]. Get the numerical simulation results of temperatures and speeds in different places. Use the thermal comfort index to analyze and evaluate the thermal environment of the gym hall. It also provides a theoretical basis and guiding value for the optimization design of the building's indoor environment.

\section{DEVELOPMENT AND APPLICATION OF CFD \\ TECHNOLOGY IN INDOOR THERMAL ENVIRONMENT EVALUATION SYSTEM}

\section{A. The Development of CFD}

Nowadays the comfort and energy saving of a building become the basic task of' architectural design. Protect the environment; use the natural energy and cut down the energy load are all the main way of architecture design in the future. In recent years, with the development of computer numerical simulation technology widely used on indoor environment, especially for CFD technology in numerical simulation of the indoor thermal environment. Of CFD is short for Computational Fluid Dynamics and it has been in the practical stage [3]. In 1974, the Danish scholar PV Nilsen used the CFD technology to calculate indoor air flow for the first time.Then people began to pay attention on the CFD technology. In 1988, Chen Qingyan used the CFD technology to analysis and studies the Building's energy consumption, indoor air flow, quality of indoor air and so on. In China, it also started in the end of 1970 's. After years of practice and research the technology has been rapidly developed and widely applied [4].

With the continuous development of modern computer technology, compared with traditional indoor environment design method, the CFD technology proves well. The comparison of the four methods are given in Table 1 for predicting indoor air temperature field and air distribution. We can see that the CFD technology has the incomparable advantage. The application of this technology shows its advantage and potential of solving practical problems [5]. And it has the very important significance. Learn from practice, the CFD solving vertical temperature and airflow distribution of large space is a relatively mature means. And it coincided with the result of the actual measurement confirmed in many cases.

\section{B. The Introduction of Airpak Software}

Airpak is the common commercial CFD software that has been used in the analysis and research of numerical simulation gymnasium this time. Airpak is software for engineers, architects and designers which is applied on the field of HVAC. It can accurately simulates the air flow, quality of air, heat conduction, pollution, comfort and some other questions of the ventilation system [6]. The application of Airpak can improve the means of design, reduce the risks and the cost. The application of Airpak software includes the architecture, 
automobile, building, chemistry, environment, HVAC, process, mining, papermaking, petroleum, pharmacy, PowerStation, print, semiconductor, communication, transportation and so on [7].

The characteristics of Airpak software as follow: 1. Quick modeling: Airpak is a modeling method which is based on the "object", and the "object" includes the models of room, human body, block, fan vent, wall, clapboard, heat load source, damping plate(block), exhaust hood; 2. Powerful ability in mesh generation 3 . The most universal models adopted; 4 . Powerful function of calculation: the solver-FLUENT is the most powerful CFD (Computational Fluid Dynamics) in the world, FVM (Finite Volume Method), the solver structured and unstructured grid, parallel algorithm that can make the UNIX and NT network all realized [8]; 5. Powerful visualization postprocessing; 6. Powerful report and visualization tools; 7. Evaluation of design and performance: post-processing includes the design assessment of product, air flow, temperature, humidity distribution, comfort, pressure and some other parameters.

TABLE I. FOUR METHODS KINDS OF AIR CONDITION- ROOM'S AIR DISTRIBUTION

\begin{tabular}{|c|c|c|c|c|}
\hline & $\begin{array}{c}\text { Jet } \\
\text { formula }\end{array}$ & $\begin{array}{l}\text { Regional } \\
\text { model }\end{array}$ & $\begin{array}{c}\text { Model } \\
\text { experimen } \\
t\end{array}$ & $\begin{array}{c}\text { CFD } \\
\text { technology }\end{array}$ \\
\hline $\begin{array}{l}\text { Complex } \\
\text { degree of the } \\
\text { room's shape }\end{array}$ & Simple & $\begin{array}{c}\text { More } \\
\text { complex }\end{array}$ & Unlimited & Unlimited \\
\hline $\begin{array}{l}\text { The } \\
\text { dependence } \\
\text { of empirical } \\
\text { parameters }\end{array}$ & $\begin{array}{c}\text { Almost } \\
\text { completely }\end{array}$ & $\begin{array}{c}\text { Dependent } \\
\text { on }\end{array}$ & $\begin{array}{c}\text { Not } \\
\text { dependent } \\
\text { on }\end{array}$ & A little \\
\hline $\begin{array}{c}\text { Cost } \\
\text { prediction }\end{array}$ & The lowest & The lower & $\begin{array}{c}\text { The } \\
\text { highest }\end{array}$ & $\begin{array}{c}\text { More } \\
\text { expensive }\end{array}$ \\
\hline $\begin{array}{c}\text { Cycle } \\
\text { predicition }\end{array}$ & $\begin{array}{c}\text { The } \\
\text { shortest }\end{array}$ & Shorter & $\begin{array}{c}\text { The } \\
\text { longest }\end{array}$ & Longer \\
\hline $\begin{array}{l}\text { Completenes } \\
\text { s of the result }\end{array}$ & Simple & Simple & $\begin{array}{c}\text { More } \\
\text { detailed }\end{array}$ & $\begin{array}{l}\text { The most } \\
\text { detailed }\end{array}$ \\
\hline $\begin{array}{c}\text { The } \\
\text { reliability of } \\
\text { the results }\end{array}$ & Bad & Bad & Best & Better \\
\hline Applicability & $\begin{array}{l}\text { Mechanical } \\
\text { ventilation, } \\
\text { related to } \\
\text { the } \\
\text { practical } \\
\text { jet } \\
\text { conditions }\end{array}$ & $\begin{array}{c}\text { Mechanical } \\
\text { and natural } \\
\text { ventilation, } \\
\text { certain } \\
\text { conditions }\end{array}$ & $\begin{array}{l}\text { Mechanica } \\
\text { l and } \\
\text { natural } \\
\text { ventilation }\end{array}$ & $\begin{array}{c}\text { Mechanica } \\
\text { l and } \\
\text { natural } \\
\text { ventilation }\end{array}$ \\
\hline $\begin{array}{l}\text { How easy it } \\
\text { is to realize }\end{array}$ & Easy & Easy & Difficult & Easier \\
\hline
\end{tabular}

\section{GENERAL PROJECT}

The gymnasium is the construction project of Dangtu's recreational activity center; consist of the competition hall, waiting room, training room and its supporting room. The competition hall of the gymnasium (includes competition and audience area), which takes a variety of events belongs to large space building. Figure I show the design sketch of gymnasium.

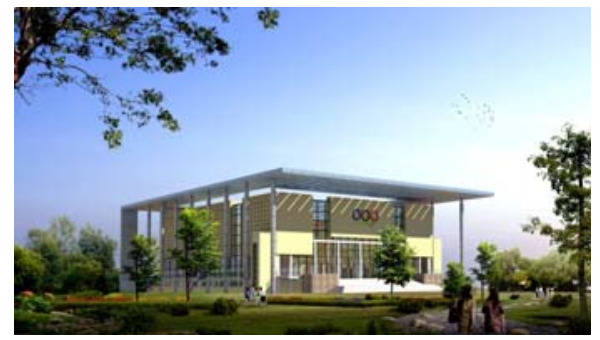

FIGURE I. THE DESIGN SKETCH OF GYMNASIUM

Choose the regular square of architectural form for the gymnasium can increase the building's usage. The length of the competition hall is about 56.8 meters, and the width is about 49.5 meters; the competition area's length is about 42 meters, and its width is about 32 meters. The total construction area is about $6350 \mathrm{~m}^{2}$, 77.6 meters long, 60.4 meters wide and 15 meters high. Three layers in total. The indoor competition area is about $1338 \mathrm{~m}^{2}$; There are 10 rows about 4 meters in the west of audience area, 18 rows in the east about 8 meters, 3 rows in both the south and north about 1.2 meters. Around the gymnasium, 4156 fixed seats and 1980 movable seats had been set up; In north-south direction of the competition hall's east side, there are two air conditioned- room [9]. They together control the competition hall's air distribution. Gymnasium is not only for sports game, but also for literature, meeting, and exhibition. It can be used as training filed when there's no competition. It belongs to integrated function gymnasium. Figure II show the profile of gymnasium

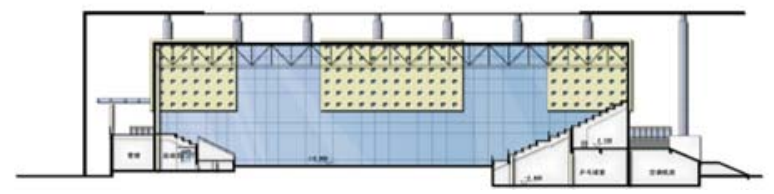

FIGURE II. THE PROFILE OF GYMNASIUM

\section{THE AiRPAK NUMERICAl SimUlation OF GyMNASIUM INDOOR THERMAL ENVIRONMENT}

To such large space building like the gymnasium, according to the air outlet position, air distribution design, blowing up blowing down and comprehensive use above the three. Due to the stadium area and the area of indoor environment is different, the stadium designers chose the game hall air conditioning using air zoning, namely the low-speed air duct air system, central air supply, the venue and seat area uses the machine part downward swirl diff user to supply air; game stands for the open situation, the use of side air, and the use of seat stands arranged evenly distributed air return inlet [10]. By numerical simulation of the air distribution design, gymnasium indoor thermal environment assessment of the situation, see if you can meet a variety of requirements in terms of speed, temperature, thermal comfort [11].

\section{A. The Decision of Summer INITIAL Conditions}

Because the stadium hall inside the building, roof design with thermal insulation material, can think of no heat exchange between the game hall and the surrounding environment [12]. 
The wall temperature is environment temperature. This research is the simulation of typical summer without the audience, so the indoor load mainly comes from the lighting.

If the top lighting is uniform distributed 12 meters below the roof, light load according to the $50 \mathrm{~W} / \mathrm{m}^{2}$ computing, namely the total lighting load for $140 \mathrm{kw}$, and by the means of a radiation load calculation, put the lighting load into convection and radiation part [13]. Sport competitions are held in the evening, so the solar radiation is no need for consideration. The audience standing the ground is also set to adiabatic boundary.

In the model, as the inner wall of building is all around, the ceiling also can be considered adiabatic. According to the design parameters of the competition hall, Indoor temperature is $25 \sim 27^{\circ} \mathrm{C}$ in summer, and $18 \sim 20^{\circ} \mathrm{C}$ in winter. The relative humidity is $<65 \%$ in summer and $<30 \%$ in winter; fresh air requirement: is $20 \mathrm{~m} 3 / \mathrm{h}$ and Indoor air velocity: the wind speed of a large ball competition ( basketball, volleyball ) is $\leqslant 0.5 \mathrm{~m} / \mathrm{s}$; The wind speed of a small ball (table tennis, badminton) in height regulated is $\leqslant 0.2 \mathrm{~m} / \mathrm{s}$. Determination of the design parameters for the competition hall: Summer indoor temperature is $27^{\circ} \mathrm{C}$,related humidity $65 \%$.

\section{B. Model}

When model the gym hall of the activity center, as its inner structure is very complex, considerated the capacity and calculation speed of the computer, we should simplified it. This competition hall is a regular square, reducing grid number and workload, we build a cuboid model. Only choose 1/4 northwest space of the competition hall when we are model. The direction size of $\mathrm{XYZ}$ is $28.4 \mathrm{~m} \times 15 \mathrm{~m} \times 24.75 \mathrm{~m}$, the competition area is $\mathrm{X}: 21 \mathrm{~m}, \mathrm{Z}: 16 \mathrm{~m}$. At the same time, the audience stands in the light of the actual situation simplified .After ignored its detailed shape, combined the calculation model with simple straight lines. The north side of the audience area is simplified to the model of one level step, its width $\times$ height is $3.96 \mathrm{~m} \times 2.4 \mathrm{~m}$. The west side of the audience area is simplified to the model of three levels steps, the every step of width and height is $5.5 \mathrm{~m} \times 2.4 \mathrm{~m}$.

Considered the big space of the whole competition, air conditioning system is offered by two air conditioning rooms. Each room is responsible for different areas of the hall's air supply. Air volume changes by the adjustment of the nozzle jet velocity. The return air inlet's set is according to the free pressure return air. 6 air ducts beared the air supply of the hall's top. There are 12 nozzles on each of the air duct, and the space is $2.8 \mathrm{~m}$. The installation height of nozzle on the air duct is $15 \mathrm{~m}, 72$ air inlets in total; Hall side blowing is used in the audience area, there are 10 both the south side and the north side. The height of the air inlets center is $8 \mathrm{~m}$. There are 12 air inlets on both the east side and the west side. Its center height of air inlets is $12 \mathrm{~m}$; The air returned through the return air inlets of the audience stand at last [14]. The south and north side of the audience area's return air inlet's height is $1.2 \mathrm{~m}$,the east and the west side respectively are: $1.2 \mathrm{~m}, 3.6 \mathrm{~m}, 6 \mathrm{~m}$, and uniformly distributed along the audience stand. In every air inlet of the model,we did the corresponding simplified processing according to a $1 \times 1 \mathrm{~m}$ size. Figure III is the simplified physical model of the gymnasium competition hall. Figure IV is the schematic diagram of grid generation.

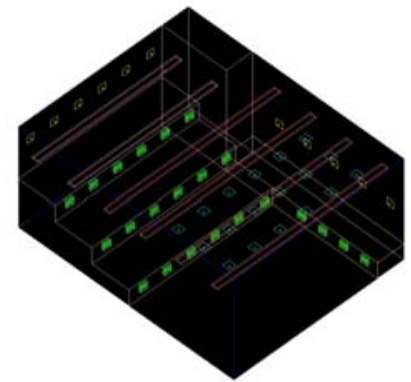

FIGURE III. THE SIMPLIFIED PHYSICAL MODEL OF THE GYMNASIUM COMPETITION HALL

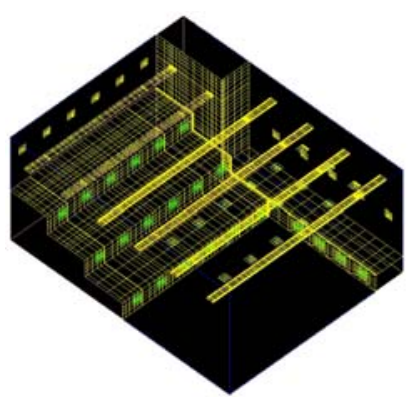

FIGURE IV. THE SCHEMATIC DIAGRAM OF GRID GENERATION

\section{Selection of control equation and boundary conditions}

In this paper, the numerical simulation of turbulent flow is using K-two equation model. The dissociation of the numerical equation is using the finite volume method. As the competition hall is inside the building, the air conditioning rooms and internal corridors are all around it, the floor, roof with thermal insulation materials and other walls can set to the adiabatic boundary [15]; At the height of $12 \mathrm{~m}$ below the roof, uniformly arranged 6 lamps, 4 of their heat release are $12000 w, 2$ of them are $11000 \mathrm{w}$; The air inlets simplified to Square nozzle with $1 \times 1 \mathrm{~m}$, the temperature of up blowing is $15^{\circ} \mathrm{C}$, the temperature of side blowing is $20^{\circ} \mathrm{C}$, the velocity of blowing is $0.8 \mathrm{~m} / \mathrm{s}$.

\section{The grid partition and computation of the model}

Put the simplified gymnasium in the center of the calculation area, parted the grid, analyzed under the situation of this air distribution, made a reasonable assessment and analysis of the gymnasium's indoor thermal environment (Figure V).

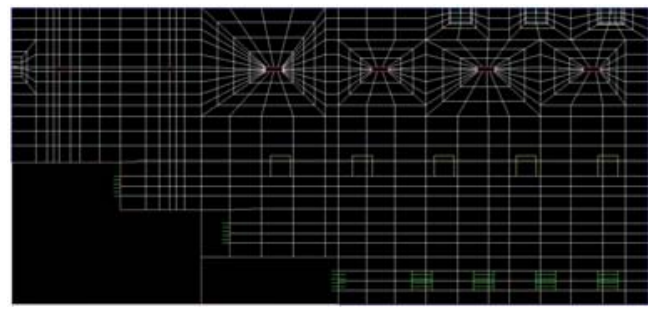

FIGURE V. MODEL Z =14.8M THE SCHEMATIC DIAGRAM OF GRID GENERATION'S CROSS-SECTION 


\section{E. The results of calculation and analysis}

1) Velocity analysis: See from the typical cross-section of velocity diagram (Figure VI, Figure VII): The velocity distribution of the whole hall is relatively stable without any big whirlpools, and the velocity all very slow. The wind velocity of audience stand mostly below $0.5 \mathrm{~m} / \mathrm{s}$, the wind velocity of front rows' is slightly higher than $0.5 \mathrm{~m} / \mathrm{s}$. The wind velocity of competition area is about $0.2 \mathrm{~m} / \mathrm{s}$, which can basically meet the requirement of small ball competition < $0.2 \mathrm{~m} / \mathrm{s}$.

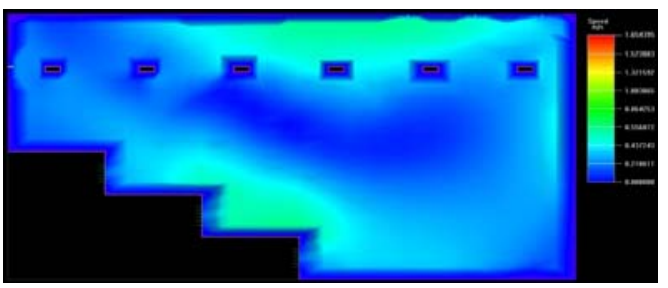

FIGURE VI. THE CROSS-SECTION WIND VELOCITY DIAGRAM

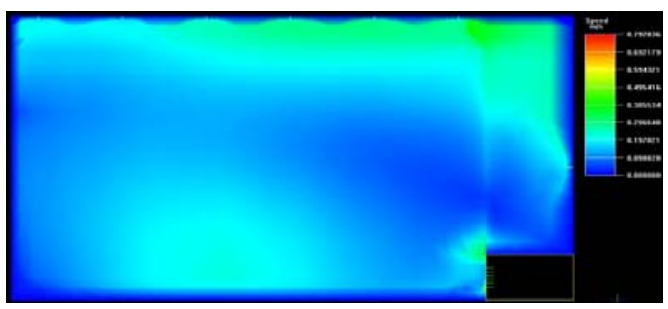

FIGURE VII. $\mathrm{X}=31.8 \mathrm{M}$ THE CROSS-SECTION WIND VELOCITY DIAGRAM

2) Temperature analysis: From the simulated typical cross-section temperature diagram (Figure VIII, Figure IX), we can see that the temperature distribution gradient of the competition hall is small, basically in the designed temperature range of $22 \sim 27^{\circ} \mathrm{C}$. Because of the audience area's personnel density in both the east and west side are bigger than the south and north side, that lead to local temperatures are slightly higher. And the movable seats area's temperature reached 28 ${ }^{\circ} \mathrm{C}$.

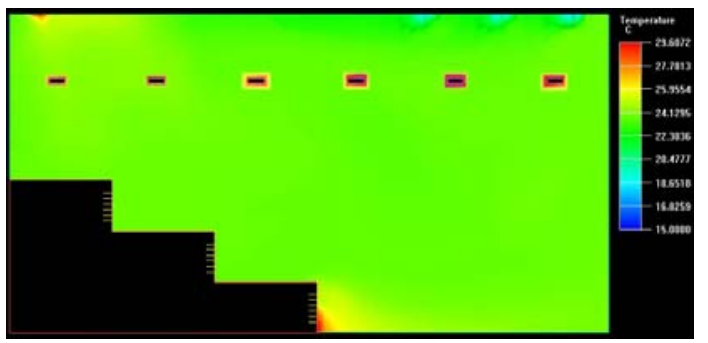

FIGURE VIII. $\mathrm{Z}=14.8 \mathrm{M}$ THE CROSS-SECTION TEMPERATURE DIAGRAM

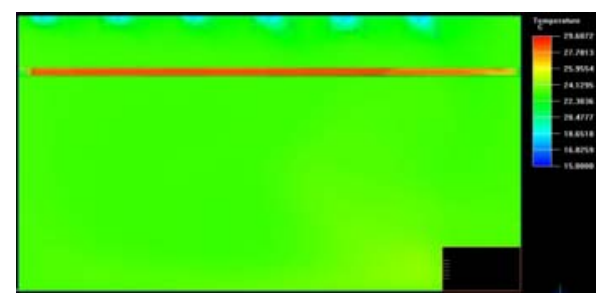

FIGURE IX. $\mathrm{X}=31.8 \mathrm{M}$ THE CROSS-SECTION TEMPERATURE DIAGRAM

3) Thermal comfort analysis: Calculated the typical crosssection PMV, PPD diagram (Figure X-Figure XIII). See from the figures, the competition area and audience area of competition hall's PMV are basically between -0.65 to 0.65 , at this range, temperatures are moderate, and people feel comfortable. From the figures, we can see the infield's load is small, so that would feel a little colder than other areas. And the comfort relationship which showed from PPD diagram already conformed to the PMV diagram [16].

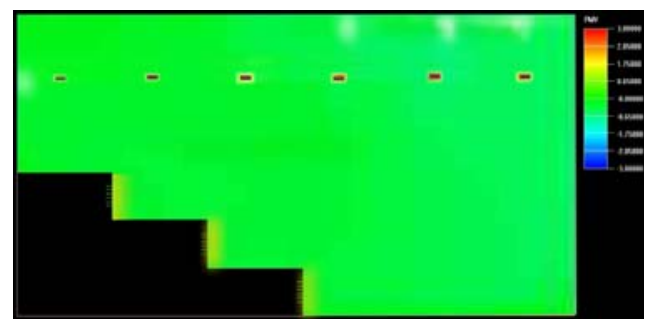

FIGURE X. $\mathrm{Z}=14.8 \mathrm{M}$ THE CROSS-SECTION PMV DIAGRAM

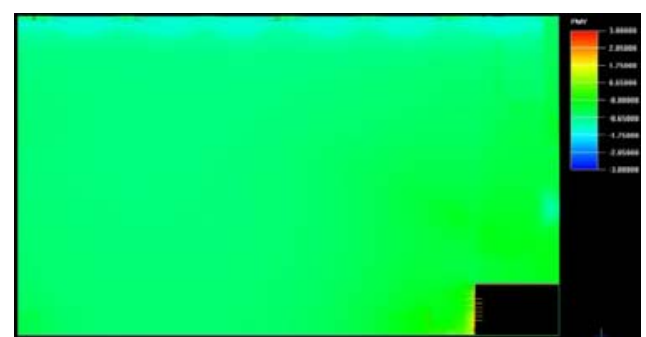

FIGURE XI. $\mathrm{X}=31.8 \mathrm{M}$ THE CROSS-SECTION PMV DIAGRAM

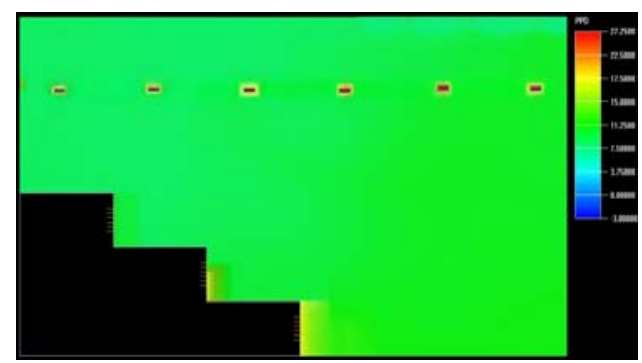

FIGURE XII. $\mathrm{Z}=14.8 \mathrm{M}$ THE CROSS-SECTION PPD DIAGRAM 


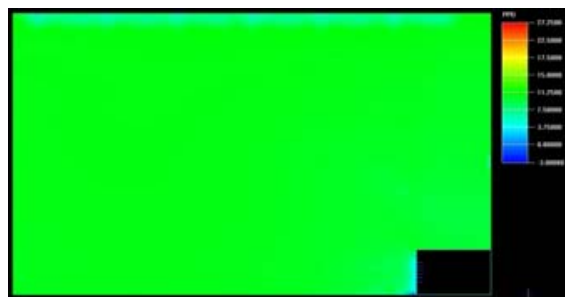

FIGURE XIII. $\mathrm{X}=31.8 \mathrm{M}$ THE CROSS-SECTION PPD DIAGRAM

From the overall, under the changing of air distribution, the most unfavorable conditions of both the temperature field and velocity field are uniform in the summer. The indoor PMVPPD value's comprehensive index basically meet the ISO 7730 to $-0.5<\mathrm{PMV}<0.5$,PPD $<10 \%$ recommended value.

4) Energy saving analysis: Reasonable air distribution can reduce the energy consumption of air conditioning from large space buildings [17]. The gymnasium designed once used the single air distribution, but it's difficult to fulfill the design requirements of indoor thermal environment. In the demonstration of repeated experiments, we find that use the single air distribution; it either cannot fulfill the requirements, or will cause a great waste. In this paper, we used the nozzles up blowing and side blowing combined air distribution form [18]. At the premise of fulfill the different requirements of every part, it can saves cold quantity about $30 \%$ in summer. It can also give full play to sense air thermal comfort effect. And it is advantageous to realize the combination of energy saving and thermal comfort.

\section{CONCLUSION}

Through the numerical simulation research and analysis of the gymnasium competition hall with using the Airpak2.1 software, we can see the progressiveness and accuracy of this technology. This technology can also provide more accurate and valuable guidance for the future design. At the same time, we found that we cannot measure the form of the gymnasium air distribution by using the single air distribution form or the single parameter standard [19]. We must combined with the project's specific situation to design out not only can fulfill the comfort requirements but also reduce the energy consumption of the building's effects. The air blowing form combined with up blowing and side blowing made the whole audience area in the recirculation zone, the wind velocity is big in local. To the large space with the dense population, a little higher indoor temperature, the bigger wind velocity will makes people fell cool; Through the nozzles 'blowing also can well controls the infield's wind velocity and fulfills the different requirements of activities.

From this research, we can find that CFD computer simulation analysis gives the actual design work great helps. The traditional designs were relied on previous people or own experiences as reference. The air distribution often improper and the errors are big. So, with the computer's rapid development, we can forecast optimize the design of buildings' indoor environment more accurate, fast, efficient by use the computer numerical simulation technology. And brings greater benefits to buildings' energy saving. Pay attention to the problem of building energy consumption. Since the HVAC energy consumption occupies $50 \%-60 \%$ of the buildings' energy consumption [20]. In view of the specific national condition of our country, how to solve the problem of building energy consumption impacts on the environment is a very important task. We should give full play to use this technology and that will makes very good guiding function for our design work.

\section{ACKNOWLEDGMENT}

This work was financially supported by national science foundation of China 51178313/E0801 and 51378365.

\section{REFERENCES}

[1] Y. P. Dong, Large space buildings' air distribution CFD simulation researches, Tianjin: Tianjin University, College of environmental science and Engineering, 2004.

[2] W. Q. Tao, Numerical heat transfer, Xi'an:Xi'an Jiao Tong University press1988.7(1).

[3] Q. Chen, Indoor Airflow, air quality and energy con-sumption of buildings. Ph D Thesis of Delft Uni-versity of Technology, Delft, 1988.

[4] G. F. Tang, Indoor air ventilation efficiency in 3D numerical analysis. Master degree thesis, Chongqing University, 2002.

[5] F. Qian, Analysis of Energy Saving Design of Solar Building-Take Tongji University solar decathlon works for example, Applied Mechanics and Materials, Vol.737, pp139-144, 2015.

[6] W. K. Chow, W. M.Leung, A Short on Achieving Convergent Results in Simulating Building Fire Using The k-Turbulent Model, Numerical Heat Transfer, part A, Vol.17,1990.

[7] Q. Y. Mei, Air flow numerical calculation and simulation. Master degree thesis. Nanjing University of Science and Technology, 2003.

[8] L. Yang, Green building design: Wind environment of building, Shanghai: Tongji University Press, 2014.

[9] Z. Lin, T. T. Chow, K. F. Fong, et al., Validation of CFD model for research into application of displacement ventilation to Hong Kong buildings, ISHVAC, 99: 3td International Symposium on Heating Ventilation and Air Conditioning, Vols 1 and 2, Editors: Zhao R Y, Burnet J, 1999, 602-613.

[10] B. Zhao, X.T. Li, X.J. Ma. The air distribution design difficulties and countermeasures of large space buildings as gymnasium, Refrigeration and air conditioning, 2002.2(2):10 14.

[11] R. Peng, Y.Q. Zou, Stratified air conditioning cooling load calculation principle, Air conditioning technology,1980,(1).

[12] L. Yang, Green building design: Building energy efficiency, Shanghai: Tongji University Press, 2016.

[13] Y.Q. Lu, Design manual heating and air conditioning, China Building Industry Press.1993.

[14] Y. Cao, Some problems of gymnasium air conditioning design. HVAC, 1991.21(5).

[15] Z.L. Ma, Y. Yao, Air conditioning system design for civil buildings. Chemical industry press. Beijing. 2003.7.

[16] X. Hu, L.C. Tan, Large space thermostat chamber flow numerical analysis. 2000 national HVAC Computer Application Seminar.

[17] J.P. Chen, Refrigeration system and air conditioning car indoor thermal micro environment coupling characteristics [Doctoral Dissertation], Shanghai: Shanghai Jiao Tong University, 1997.

[18] China Academy of Building Research Institute of air conditioning. Tall building air conditioning technology Research Report.1982.

[19] W.D. Long, New concepts of building energy conservation. HV\&AC, VOL29, NO.1,1999. 
[20] C. A. G. Fletcher, I. F. Mayer, A. Eghlimi, K. H. A. Wee. CFD as a Building Services Engineering Tool, Architectural Science, 2001, 2(3): 67-81. 